\title{
Cosmetic Dermatitis
}

\author{
東禹 彦*
}

Nobuhiko HIgASHI, M.D.

Patch test and photo-patch-test are carried out in patients with cosmetic dermatitis. The test results indicate that the untoward reactions to cosmetics are due predominantly to allergic sensitization rather than to primary irritation.

It is said that false negative reactions are common in testing with cosmetics, depending upon the test materials and test methods.

Five days or more after contact with the causative substance the sensitive states will develop. No sensitivity appears after repeated contact with cosmetics for many years in most individuals. Some may become sensitive after continual contact over a period of years.

The past history about the cosmetics has to be thoroughly inquired in patients with cosmetic dermatitis. All cosmetics that the patient has used must be taken into consideration. Cosmetics are used on the uncovered areas, so that photo-patch-test as well as patch-test must be carried out to determine the causatives. Thus, false negative reactions are avoidable.

A trial to determine the actual cause of sensitivity encounters the practical difficulties because of the industrial secret on cosmetic ingredients. Knowledge of the sensitizing ingredients of cosmetics is scanty.

われわれの生活環境には接触皮膚炎の原因となり得る ものが数限りなく存在し, 文明の進歩とともに原因物質 は増大し，更にそれとの接触機会も増加する。

皮膚科医が遭遇する疾患中最も多いものは湿疹と称さ れるものであるが, 接触皮膚炎に関する知識の増加とと もに，それら湿疹とされていたもののらちかなりのもの が接触皮膚炎であることが判明するようになった。接触 皮膚炎においでは接触原を見い出すことが肝要であるが， 一見しては接触皮膚炎と見えない例も多数存在する。 古谷ら ${ }^{1)}$ の報告では顔面に限局した湿疹・皮膚炎患者の 男女比は実数で約 $1: 8$ であって圧倒的に女性に多い。 10 才台では男女比に差がないにもかかわらず， 20 才 台，30 才台では女子に多発している。早川ら²) も同様 の統計を発表している。これら統計は女子顔面限局性皮 膚炎に化粧品の関与が並並ならぬものであることを示唆 している。リール黒皮症は男子における発生はまれであ るが, 古谷ら ${ }^{1)}$ は男性用化粧品を 2 年有余にわたり使用

* 大阪市立大学医学部皮膚科教室 (大阪市阿倍野区旭 町 1-61)

From the Department of Dermatology Osaka City University Medical School, Osaka, Japan
していた男子に発生した例を記載している。このように 顔面に発生する皮膚炎のかなりのものが化粧品と因果関 係があると考えられている。

\section{1. 接触皮膚炎について}

接触皮膚炎は発生機序から Table-1 で示すように4 つに分類されている ${ }^{3)}$ 。大多数の人に 1 数回の接触で 皮膚炎を生じるような起炎物質で惹起される皮膚炎が一 次刺激皮膚炎である。たとえば強い酸やアルカリの接触 によって生じる。光毒性接触皮膚炎は光線の作用が加わ って初めて生じるもので, たとえばベルロック皮膚炎が そうである。

アレルギー性接触皮膚炎の発症には個体と抗原との接 触により感作の成立することが前提となっている。

Table-1. Classification of Contact Dermatitis on Etiological Grounds

1. Primary irritant dermatitis

a) Toxic dermatitis

b) Cumulative insult dermatitis

2. Allergic contact dermatitis

3. Phototoxic dermatitis

4. Photo-allergic dermatitis 
アレルギー性接触皮膚炎の原因となっているものの多 くは低分子の物質であって, それ単独では抗原性を発揮 しないものが多い。アレルギー性接触皮膚炎の発生機序 は「皮膚より吸収された低分子物質 (hapten) が皮膚の 担体蛋白 (carrier protein) と結合して完全抗原となり, これがリンパ管を通ってリンパ節に運ばれ, リンパ節で 抗体産生細胞を刺激して抗体を産生する。産生された抗 体はリンパ球に含まれて, 全身の皮膚を感作する」と考 えられている。光アレルギー性接触皮膚炎の場合は皮膚 から吸収された低分子物質が光線の作用で変化をうけ, それが hapten となると考えられている。そして感作の 成立には一定の期間が必要である。催涙ガス $\mathrm{CN}(\mathrm{w}-ク$ ロロアセトフェノン）や実験的に接触皮膚炎を惹起する のに使用される DNCB は感作能力の高いものであるが これらによっても感作されない個体も存在する。 ${ }^{3,4)} こ$ のような感作能力の強、物質では皮膚に 1 回塗布するだ けでアレルギー性接触皮膚炎を生じ得るが，すなわち自 然再燃 (spontaneous flare-up) が一次刺激皮膚炎に引 続いて見られるが，普通は感作成立には 1 回以上の投与 が必要である。感作成立に要する期間は区区であって, 毎日連用して数カ月以上要することもまれではない。感 作の成立には体質が関与しているのは明らかであるが, その他には局所因子として損傷された皮膚に抗原が適用 されるならば感作は成立しやすくなる。 ${ }^{3,5)}$

ある物質が使用されるようになってから期間が長くな ればなるほど，また使用される人口が増大すればするほ ぞ, その物質に感作される個体は増加するので, その物 質によるアレルギー性接触皮膚炎の頻度はしだ、に増加 するのである。

\section{2 貼 布 試 験 ${ }^{3,6)}$}

接触原を見い出す方法としては貼布試験が行なわれて いる。露出部に使用する機会の多い化粧品が原因と考え られる接触皮膚炎では光貼布試験 (photo patch test) は必須のものである。

方法：貼布試験用絆創高（2 種類市販されている）の

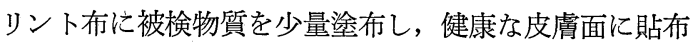
する。貼布時間は 48 時間が一般に推奨されている。光 貼布試験は Fig.-1 でに示すように対照として貼布試験 単独および光線照射単独の 2 つを扤く必要がある。光貼 布試験の光源としては太陽光線が最良であるが，外来診 療においてはその利用が不可能であるので, 著者は人工 太陽燈を利用している。照射量は最少紅斑量以下でなけ ればならない。

貼布試験に用いる被検材料は接触した物質そのものを

Fig. 1 光貼布試験

(1)

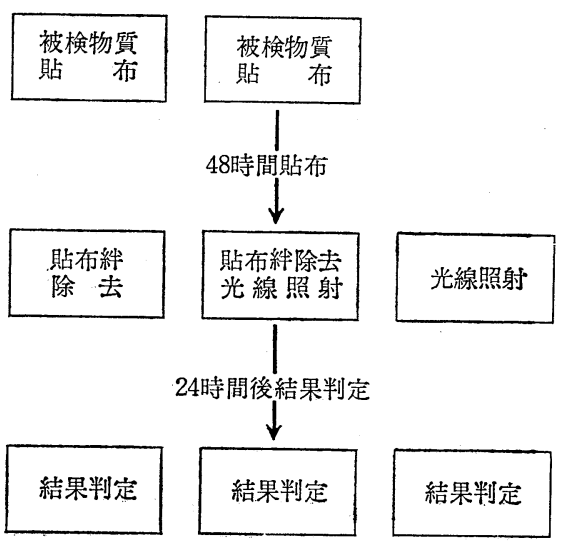

(1)、(3)の対照に比して(2)の 反応が結果判定において最 強であれば光アレルギー接 触皮虑炎の原因と考元られ る。MED 以下照射してい れば(3)は陰性のはずである。

用いるのが最良であるがが，接触原が全く不明の時には 市販の貼布試験試薬を用いている。

判定：48 時間後に貼布片を剝がし， 30 分待って判 定する（筆者はこの時間を利用して光照射を行なってい る)。瘙痒, 発赤, 丘疹, 浮腫, 水疮などがあれば陽性 と判定している。陽性反応を呈するのには一次刺激反応 の場合とアレルギー性反応の場合があり，その区別は Table-2 のような基準で行なわれている。日常使用して

Table-2 アレルギー反応と一次刺激反応の区別

\begin{tabular}{|c|c|c|}
\hline & アレルギー反応 & 一次刺激反応 \\
\hline 反応持続時間 & $\begin{array}{l}\text { 抗原除去後も存続 } \\
\text { し，数罝はかえ } \\
\text { つて增強すること } \\
\text { がある。 }\end{array}$ & $\begin{array}{l}\text { 反応は抗原除去 } \\
\text { 後急速に消褪す } \\
\text { る。 }\end{array}$ \\
\hline $\begin{array}{l}\text { 抗原稀釈に対 } \\
\text { する反応 }\end{array}$ & $\begin{array}{l}\text { 抗原濃度を稀釈し } \\
\text { む陽性反伈を示 } \\
\text { す。 }\end{array}$ & $\begin{array}{l}\text { 抗原濃度を稀釈 } \\
\text { すれば反応は陰 } \\
\text { 性化しやすい。 }\end{array}$ \\
\hline
\end{tabular}

いる物質で貼布試験を行なって陽性反応を呈すれば，そ れは当該接触皮膚炎の原因と考えてよいので，この区別 は重要でない。一次刺激反応かアレルギー反応かの区別 は貼布試験試薬を用いて貼布試験を行なった場合には必 要であるし，また貼布試験試薬や工業製品（化粧品を含 めて）を市販する前段階として貼布試験（predictive patch test) を行なった場合にはきわめて重要である。 これらの製品で一次刺激皮膚炎を生じるものが市販され てはならないからである。 
問題点：貼布試験を行ならことによって真の原因を見 、出し，今後同一原因による皮膚炎を生じないようにす る必要がある。そのためには日常使用している製品によ る貼布試験に引続いて, その製品の構成成分による貼布, 試験を行なわなければならない。しかし，現在では臨床 医に工業製品に関する知識がそしく，また工業製品の成 分が公にされていないものが多く，そのために真の原因 が見い出せないことが多い。この点については今後企業 の積極的な医師に対する協力が必要ではなからうか。両 者の協力によって, 感作能力の強い物質は日常使用する
製品から除外していく必要がある。

\section{3 化粧品皮膚炎}

化粧品皮虐炎は大きくわければ急性症状（強い瘙痒, 発赤，浮腫，丘疹および小水疮を伴なう）を呈する型と 慢性に経過する型（自覚症状の少ないもの）がある。前 者においては患者自身が化粧品に疑いをもつし，医師も 原因に気付きやすいが，後者においては患者も医師も原 因に気付かない例が多い。

Table-3 化粧品皮膚障害症例

\begin{tabular}{|c|c|c|c|c|c|}
\hline $\begin{array}{l}\text { 番 } \\
\text { 号 }\end{array}$ & $\begin{array}{l}\text { - 年 } \\
\text { 令 }\end{array}$ & $\begin{array}{l}\text { 性 } \\
\text { 別 }\end{array}$ & 部 & $\begin{array}{l}\text { 貼布試験 } \\
\text { 実 施 数 }\end{array}$ & 貼 布 試 験 性 物 質 \\
\hline 1 & 28 & 우 & 両頉 & 3 & カラーパック, クレンジングクリーム, 乳液 \\
\hline 2 & 36 & 우 & 眉 & 12 & 盾墨 \\
\hline 3 & 46 & 우 & 両頓，鼻 & 3 & レモン乳液 \\
\hline 4 & 29 & 우 & 両頓 & 12 & 化粧下クリーム \\
\hline 5 & 36 & 우 & 両煩 & 6 & マッサージ・クリーム \\
\hline 6 & 21 & 우 & 両煩 & 7 & 化粧水 2 種, コールド・クリーム \\
\hline 7 & 42 & 우 & 両规 & 20 & $\begin{array}{l}\text { クレンジング・クリーム, ファウンデーション } \\
\text { 固型白粉, コールド・クリーム }\end{array}$ \\
\hline 8 & 40 & 우 & 両頓 & 4 & ファウンデーション \\
\hline 9 & 19 & 우 & 顔 & 3 & スキン・ローション \\
\hline 10 & 21 & 우 & 両煩 & 5 & マッサージ・クリーム, リキッド・メイクアップ \\
\hline 11 & 20 & 우 & 顔 & 12 & 乳液, \\
\hline 12 & 42 & 우 & 両煩 & 5 & 整肌用化粧水, 洗顔用化粧水, 他 2 種 \\
\hline 13 & 41 & 우 & 顔 & 10 & 洗顔クリーム \\
\hline 14 & 45 & 우 & 被髪頭部 & 5 & ヘアダイ 1 液, パラフェニレ |ジアミン \\
\hline 15 & 52 & 우 & 眼瞼, 両類 & 5 & 乳液，ヘキサクロロフェン \\
\hline 16 & 21 & 우 & 両煩 & 10 & ファウンデーション, パンケーキ \\
\hline 17 & 26 & 우 & 顔 & 8 & 乳液, 化栍水 \\
\hline 18 & 28 & 우 & 顔 & 35 & 17種で陽性 \\
\hline 19 & 37 & 우 & 顔 & 4 & 洗顔パスタ \\
\hline 20 & 45 & 우 & 顔 & 3 & マッサージ・クリーム，ファウンデーション \\
\hline 21 & 21 & 우 & 顔 & 6 & ファウンデーション \\
\hline 22 & 50 & $\hat{\delta}$ & $\begin{array}{l}\text { 被髮頭部，手掌 } \\
\text { その他 }\end{array}$ & 2 & ヘアー・クリーム \\
\hline
\end{tabular}

最近著者が経験した化粧品皮膚炎の症例で，貼布試験 により原因の判明したものを Table-3 に示し，代表的 な症例について詳述する。

症例 128 才。主婦。

44 年 1 月にカラー・パック使用後両頖部全体に発赤, 腫脹を生じ，それ以後しだいに該部に色素沈着を生じる ようになった。カラー・パックはそれ以後使用していな い。初診時 (44 年6月) 両顂部に軽度の発赤, 苔癬化,
落屃および褐色の色素沈着を認めた。貼布試験でカラー ・パック陽性, 現在使用中の乳液およびクレンジング・ クリームは光貼布試験で陽性を示した。化粧品の使用を 禁止してからは瘁痒感, 発赤, 落屑ともに消失し, 1 年 後の現在では軽度の色素沈着を見るのみで, 皮膚表面は ほぼ正常となっている。 症例 236 才。主婦。 数力月来両眉毛部に軽い櫁痒を伴った落屃性の紅斑を 
生じているために来院。現在使用中の化粧品 12 種で貼 布試験を行なったが，眉墨のみが陽性反応を呈した。 症例 429 才。主婦。

3 日前より顔面ことに両颕部に瘁痒を伴った粟粒大の 紅色丘疹を生じて来院。新らたに使用した洗顔クリーム が原因ではないかと訴えた。貼布試験を行なったところ 下地クリームのみ陽性で, 他の使用中の化粧品および患 者が原因と考えていた洗顔クリームは陰性であった。

症例 1341 才。主婦。

3 カ月来顔面全体に軽度の瘙㾕感と軽い発赤が続いて いるために来院。使用中の化粧品 10 種による貼布試験 を行なったところ，洗顔クリームのみ陽性を示した。洗 顔クリームの使用を中止し, 皮疹は改善した。

症例 1726 才。女子店員。

2 日前に $\mathrm{O}$ 社製の化粧水を使用したところ顔面全体に 発赤, 腫脹を生じたと訴えて $\mathrm{O}$ 社販売員同道で来院。貼 布試験の結果は以前より使用していた乳液および化粧水 で陽性反応を呈したが，患者が原因と考えていた $\mathrm{O}$ 社製 化粧水は陰性であった。

症例 22 50才。男子事務員。

本年 3 月 初めより 被髪頭部, 手掌に瘙痒を 伴った紅 斑, 落屑を生じ， 3 月中旬に被髪頭部の皮疹が湿潤化す るとともに，ほとんど全身に瘙㾕性紅斑を散在性に生じ るようになり来院した。

感染性湿疹状皮膚炎および自家感作性皮膚炎として副 腎皮質ホルモンの内服を行なった。被髮頭部および手掌 の皮疹を除く他部皮疹は副腎皮質ホルモン内服で一時軽 快したが，その減量と共に被髪頭部，手掌の皮疹が悪化 し，再び四肢，躯幹にも皮疹の出現を見た。副腎皮質木 ルモンの増量でやや軽快, 減量で悪化するという経過を 3 回繰り返すうちに，接触皮虞炎という印象が強くな り，皮疹の分布が手掌と被髪頭部であることから整髪料 が原因ではないかと推定し，へヤクリーム，モイスチャ ークリームによる貼布試験を行なった。副腎皮質ホルモ ンおよび抗ヒスタミン剂内服中にもかかわらず，へヤク リームは強陽性を示した。このへヤクリームは 3 年来使 用していたもので，患者は原因とは全く思っていなかっ た。ヘヤクリームの使用を中止し, '皮疹は急速に軽快し た。

以上の例症についてみてもわかのであるが，急性症状 を呈した例では症状発現後数日を経ずして来院し，化粧 品が原因と訴えているが，慢性に経過している症例では 症状発現後来院までの日数が長く, 本人は化粧品が原因 とはほとんで考えていない。急性症状を呈した例では， 本人が原因と推定した化粧品と原因となった化粧品とが
異なっていることもしばしば経験する。例えば早川22)の

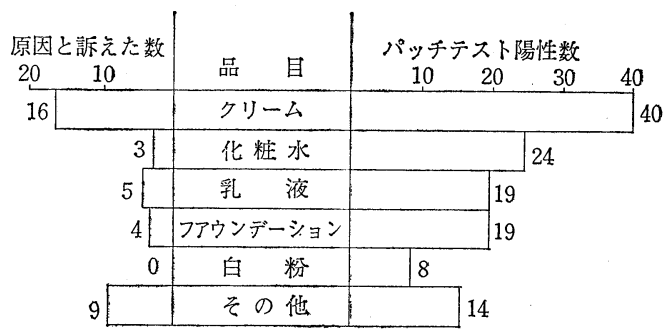

Fig.-2 患者の訴光た品目と Patch Test 陽性品 目との差（42 名について）

調查でも明らかであって Fig.-2 に示すよらに，本人の 訴えと貼布試験陽性化粧品の間には大きなずれがある。 患者は白粉のように最外層に使用する化粧品や長期間使 用している化粧品を原因から除外する傾向にある。した がって患者の持参した化粧品のみで貼布試験を行なえば 陰性の結果を得，現存する皮疹が化粧品によるものでな いといら誤った結論に導かれる可能性がある。このよう な誤りを避けるために, 筆者は症例 2 のように眉墨が原 因と推定した例であっても洗顔石簽から基礎化粧品, メ イクアップ製品と患者が顔面に使用するもの全てで貼布 試験を行なっている。

これまで化粧品皮虔障害を疑った患者では，ほとんど 全ての例で原因となった化粧品が判明し，それを中止す ることにより臨床的にも皮膚障害が軽快している。そし て大多数の例がアレルギー性接触皮膚炎と考えられるも のであった。しかし，中村7は初めて使用した化粧品で 皮膚炎が発生した例が多く，その化粧品が一次的な起炎 刺激として作用したと考え，化粧品皮膚炎の大部分はそ の個人に対して当該化粧品が一次的に中毒性に作用して 起る一種の dermatitis toxica と考えたいと述べてい る。自験例中にも新たに使用した化粧品で発症した例も あるが，以前から使用していた化粧品が原因であること が多く，化粧品を新たに使用した時期と皮膚炎の発生が 偶然一致したに過ぎないことが多い。そして後者の場合 には患者も医師も原因を新たに使用した化粧品と思いが ちである。

古谷ら ${ }^{1)}$ は化粧品皮膚炎を疑った症例で貼布試験陽性 率が低く，原因を発見できなかったことが多いと記して いるが，彼らの場合には光貼布試験を行なっていないの である。リール黒皮症, 女子顔面黒皮症における化粧品 貼布試験成績は陽性率の低い報告8,9)が多いが斎藤10)は 39 例中 24 例において陽性であったという。女子顔面 再発性皮膚炎の原因は化粧品と考えられているが11,12) 
(反対意見もある $\left.{ }^{13}\right)$ )，化粧品貼布試験の陽性率は $100 \%$ ではない。これらの慢性の経過をとる症例で陽性率が低 いのは検査の方法が適切でないことに基づくのである。 光貼布試験を行なっていない報告があり，また検査化粧 品数が充分でないように思われる。経過の長い症例にお いてはその間に使用した化粧品全てによる検索を行なわ ねばならない。

\section{4 化粧品皮膚炎の治療ट化粧}

化粧品皮膚炎の治療にとって最も大事なことは原因の 除去である。症例 22 のように数力月にわたる対症療 法で全く軽快しなかったものが，原因が判明し，それを 除去することによってすぐに軽快する。

急性症状を呈する型では患者も化粧品皮膚炎であると いう自覚があり，治療も容易であるが，慢性に経過する 型では本人に化粧品皮膚炎という自覚が少なく，治療に 非協力的である。後者の場合にはわれわれが化粧品皮膚 炎であることを指摘しても納得せず，貼布試験によって ようやく本人に原因を納得させているのが現状である。 慢性に経過する型はしだいに色素沈着をきたし，ついに は治療を行なっても色素沈着が軽減し難くなるが，早期 に治療を開始し，化粧品の使用を禁止すれば大抵は治癒 する。

急性型においても慢性型においても治療上重要なこと は原因となった化粧品を使用させないのは当然である が，化粧品皮膚炎が存在する間は化粧品を一切使用させ ないことである（著者は洗顔石醶で添加物の少ないもの のみ使用させている)。その理由は皮膚炎が存在する部 位では一次刺激皮膚炎が生じやすく，また障害された皮 膚に対する化粧品の使用はその化粧品による感作が成立 しやすくなるからである。色素沈着を伴った症例では, 患者は色素沈着を隠すために化粧を厚くする傾向があ り，そのために治瘳しないのみならず色素沈着が増大 するのである。リール黒皮症における貼布試験の成 績10,14) では，同時に多数の化粧品に対して陽性を示す ことが多いと報告されている。これは各種化粧品に同一 成分が含まれている可能性や交差感作が生じている可能 性もあるが, 前述の理由で多数の化粧品に感作されるよ うになる可能性も示している。女子顔面黒皮症（リール 黒皮症) は難治であるが, 症例 1 で示されるように，化 粧を中止すれば瘁痒はかなり早期に消裉し，1 2 年で 色素沈着も著るしく軽快すうのである。これまでの経験 では化粧を継続していて軽快した例はあまりない。

接触皮膚炎が完治した後に，化粧を再開するのは差支 えないが，その際にはやはり貼布試験, 光貼布試験およ
び使用試験を行なって, 化粧品の安全性を確認しなけれ ばならない。そして安全性を確認した化粧品を使用した としても, それは終生安全という保証はないのであるか ら, もし使用中になんらかの異常が生じれば, すぐに再 検査を行なう必要がある。

\section{5 化粧品皮膚障害の予防対策}

化粧品皮膚障害の発生頻度に関する正確な統計はない が, 早川ら²)のアンケートによる調査では化粧品使用者 の $19 \%$ がなんらかの障害を受けた経験があるとされ， 特に $\mathrm{P}$ 社化粧品使用者における障害率は $40.5 \%$ である と報告されている。また 1 カ月に化粧品に費す費用が高 くなるほど障害率が高いことも指摘されている2)。

Table-4 アンケートによる銘柄別障害率（早川）

\begin{tabular}{l|r|r|r|r|r|r|r}
\hline & $\mathrm{S}$ & $\mathrm{P}$ & $\mathrm{M}$ & $\mathrm{Ka}$ & $\mathrm{Ko}$ & $\mathrm{A}$ & \multicolumn{1}{c}{ 計 } \\
\hline 使用者数 (名) & 609 & 121 & 266 & 182 & 79 & 93 & 1350 \\
障害者数 (名) & 129 & 49 & 16 & 24 & 9 & 29 & 256 \\
障害率 (\%) & 21.1 & 40.5 & 6.1 & 13.2 & 11.4 & 31.2 & 19.0 \\
\hline
\end{tabular}

註） Aはその他の銘柄

化粧品によるアレルギー性接触皮膚炎の発生をなくす ことは不可能であろうと考えているが，現在の障害率は 高すぎるようである。種種な対策によって化粧品皮膚障 害の発生頻度を低下させることは可能である。そのため には1）新たに感作されることを減らすために，化粧品 皮膚炎があるときには全ての化粧品の使用を避けるこ と。2）感作能力の強い成分を化粧品に使用しないこと。 3）構成成分の種類が多いほど 製品全体としての 感作能 力は増大するので, 構成成分の種類を減らすこと, など が必要である。

新たに開発された物質について感作能力の強弱を検討 するには，かなりの期間とかなりの被検者が必要であ る。たとえば，貼布試験 (predictive patch test) 200 人に行なって全て陰性の結果を得た製品であっても，実 際には市販し多数の人に使用されるようになれば 38 人 中 1 人に接触皮膚炎を生じる可能性があり，5300人に 貼布試験を行なって全て陰性であっても，市販すれば 1000 人に 1 人は接触皮膚炎を生じる可能性があると統 計学的には考えられている15)。したがって，普通の方法 で検討しても感作能力の強弱を見いだすのは困難であ る。感作の成立は, 体質, 皮膚局所の状態や使用期間が 影響するが，物質の濃度も大きな影響を及ぼしている。 たとえば $p$-aminophenol を 10\% にラノリンに含有し たものでは被検者の $6 \%$ に感作を生じ得るが, $2 \%$ に含 有するものではほとんど感作は成立しない。3) しばしば 
軟育に含有されている paraben も $5 \%$ では感作率が高 いが， $0.5 \%$ では感作される個体は減少する。 ${ }^{16)}$ それ ゆえに predictive patch test は一次刺激刺皮膚炎を生 じない範囲の高濃度の物質を障害皮膚に頻回に 適用し て, 被検者の感作率を高めたらえで, 正常皮膚に常用濃 度の物質を貼布して行なえばよい。このような方法であ れば,かなりの程度にその製品の感作能力を知ることが できるであろう。

一方, すでに市販されている化粧品に含まれている成 分については医師と企業の協力さえあれば感作能力の強 、物質を見いだすことは簡単である。現在市販の化粧品 の構成成分が不明であるので, 多数の化粧品に感作され ている場合に, それが同一物質によるものか, 交叉感作 によるものか, 全く別個の物質によるものかさえ決定す ることができない。真の原因を突き止め, 化粧品皮膚障 害を減少させていくためには企業と医師の協力が必要で あるが，現在では十分とはいえない。協力の一つの段階 として医薬品と同様に化粧品にも含有成分の表示がなさ れることが望まれるのである。

\section{むす び}

最近経験した症例を中心に, 化粧品皮膚障害について, 臨床医の立場から原因検索法, 治療法, 予防対策などに ついて私見を述べた。

な掞本論文は 6 月 24 日大阪化粧品技術者会例会で行
なった講演を基とし, 当日受けた質問に対する解答も含 めて記述したものである。(昭和 45 年 8 月 8 日受理)

\section{文献}

1）古谷達孝, 鳥居ユキ, 皮膚臨床, 6,311 (1964)

2) 早川律子, 井沢洋平, 小林敏夫, 皮膚臨床, 10,979 (1968)

3) Rook, A., Wilkinson, D. S. and Ebling, F. J. G., Textbook of Dermatology, Blackwell, Oxford and Edinburgh, 1968, pp 238-322.

4）田代実, 西岡清, 皮膚, 12, 12 (1970)

5) Kligman, A. M., J. Invest. Derm., 46, 573 (1966)

6）斎藤文雄，皮膚臨床，4，354（1962）

7）中村敏郎，皮膚臨床， 6, 329 (1964)

8）三島豊，皮と泌，18，509（1956）

9）加納魁一郎，皮膚臨床，4, 90 (1962)

10）斎藤文夫，皮膚臨床，6,333 (1964)

11）大原一枝, 皮紀要, 42, 273 (1943)

12）栗原 善, 皮紀要, 35, 1 (1940)

13）皆見省吾, 臨床皮膚, 24, 59 (1970)

14）安田利顕, 上野雅子, 診断と治療, 58, 219 (1970)

15) Eskelson, Y.D. and Goodman, L. S., JAMA, 183, 136 (1963)

16) Schorr, W. P. and Mohajerin, A. H., Arch.

Derm., 93, 721 (1966) 